\title{
The synergistic effects of low-dose irinotecan and TRAIL on TRAIL-resistant HT-29 colon carcinoma in vitro and in vivo
}

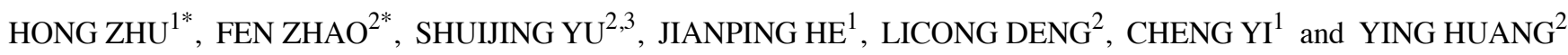 \\ ${ }^{1}$ Department of Abdominal Cancer, West China Hospital and ${ }^{2}$ Department of Pathophysiology, \\ West China School of Preclinical Sciences and Forensic Medicine, Sichuan University, Chengdu, Sichuan 610041; \\ ${ }^{3}$ Shenyang Xin Zhuoyue Machinery Import and Export Company Limited, Shenyang, Liaoning 110021, P.R. China
}

Received May 11, 2012; Accepted July 23, 2012

DOI: $10.3892 /$ ijmm.2012.1105

\begin{abstract}
Tumor necrosis factor-related apoptosis-inducing ligand (TRAIL) is a member of the tumor necrosis factor superfamily that induces apoptosis in a broad range of human cancer cell lines while sparing most normal cell types. However, many tumors remain resistant to treatment with TRAIL. In this study, we investigated the synergistic effects of low-dose irinotecan (CPT-11) and TRAIL on TRAIL-resistant HT-29 colon carcinoma cells and explored potential mechanisms of apoptosis. Cell viability was analyzed by sulforhodamine B (SRB) assay and apoptosis was evaluated by flow cytometry and DNA ladder assay. The mRNA expression of TRAIL receptors death receptor 4 (DR4) and DR5 were determined by reverse transcription polymerase chain reaction (RT-PCR). The changes of Bax and caspase-9 in protein levels were also detected by western blotting. Tumor growth curves were depicted and tumor inhibitive rates were calculated. Our results showed that the antitumor effect of TRAIL could be enhanced significantly by low-dose CPT-11 on TRAIL-resistant HT-29 cells both in vitro and in vivo. The synergistic apoptotic effect of CPT-11 and TRAIL was proposed to be mediated by upregulating DR5 mRNA expression and increasing expression of Bax and caspase-9 proteins. The data suggest that the combination of TRAIL with low-dose CPT-11 could be an effective therapeutic approach for HT-29 colon carcinoma.
\end{abstract}

Correspondence to: Professor Ying Huang, Department of Pathophysiology, West China School of Preclinical Sciences and Forensic Medicine, Sichuan University, Chengdu, Sichuan 610041, P.R. China E-mail: huangying68@163.com

Professor Cheng Yi, Department of Abdominal Cancer, West China Hospital, Sichuan University, Chengdu, Sichuan 610041, P.R. China E-mail: yicheng6834@163.com

*Contributed equally

Key words: tumor necrosis factor-related apoptosis-inducing ligand, irinotecan, TRAIL receptor, colon carcinoma, apoptosis, synergism

\section{Introduction}

Colorectal cancer is the most frequent malignancy of the digestive tract, and one of the most common types of solid organ cancer in both males and females in developed countries. Worldwide, approximately 1 million cases are recorded annually, and over half a million patients succumb to this disease each year (1). Irinotecan (CPT-11) is a topoisomerase I inhibitor widely used in the treatment of colorectal tumors (2). However, the use of CPT-11 in a clinical setting has been hampered by modest efficacy and significant toxic side-effects (3). Thus, novel treatment strategies are urgently needed to improve the clinical management of colorectal cancer.

Tumor necrosis factor-related apoptosis-inducing ligand (TRAIL), a tumor necrosis factor superfamily member has been shown to induce apoptosis. TRAIL can bind to 5 different receptors: TRAIL-R1 (death receptor 4, DR4), TRAIL-R2 (DR5), TRAIL-R3 (decoy receptor, DcR1), TRAIL-R4 (DcR2) and osteoprotegerin (OPG). DR4 and DR5 are the death receptors that signal for apoptosis, whereas DcR1, DcR2 and OPG are considered antagonistic as they are unable to induce such signaling due to the lack of intracellular death domain or are secreted molecules (4). TRAIL triggers apoptosis through binding to its receptors (DR4 and/or DR5) in a broad range of human cancer cell lines while sparing most normal cell types (5). Thus, TRAIL is a promising cancer therapeutic agent due to its tumor selectivity (6). Several studies have previously demonstrated that many colon carcinoma cells were sensitive to TRAIL both in vitro and in vivo except for HT-29 $(7,8)$. They also found that CPT-11 enhanced the antitumor effects of TRAIL on HT-29 colon carcinoma (9). However, the focus was mainly on the TRAIL sensitive colon carcinoma cell lines such as COLO 205, SW948, and HCT116, and the synergistic effects of TRAIL and CPT-11 on HT-29 were not studied thoroughly (7). In this study, we investigated the combined effects of TRAIL and CPT-11 at different doses and explored the potential apoptosis mechanism on TRAIL-resistant HT-29 colon carcinoma cells in vitro and in vivo.

\section{Materials and methods}

Materials. Human HT-29 colon carcinoma cell line and TRAIL were provided by DIAO Group (China). Female 
nude mice ( 6 weeks old) were purchased from the animal experimental center of the Chinese Academy of Science, Shanghai (China). CPT-11 was purchased from Aventis (France). Sulforhodamine B (SRB) was supplied by Sigma (USA). Roswell Park Memorial Institute (RPMI)-1640 medium and trypsin were purchased from Gibco (USA). Mouse monoclonal antibody for Bax was purchased from Santa Cruz Biotechnology, Inc., (USA). Mouse monoclonal antibody for $\beta$-actin was purchased from Abcam (UK). Mouse monoclonal antibody for caspase- 9 was purchased from Lab Vision (USA). LSAB kit was purchased from Dako (Japan). Goat anti-mouse IgG-HRP was purchased from Rockland (USA). TRIzol kit and apoptotic DNA ladder kit were purchased from Bioteke Corporation (China). One-step RT-PCR kit was purchased from Takara Biotechnology Co., Ltd., China. Polyvinylidene difluoride (PVDF) membrane was purchased from Millipore. Enhanced chemiluminescence (ECL) detection kit and X-ray film were purchased from Roche (Switzerland). Annexin V-FITC apoptosis detection kit was purchased from Jingmei Biotech Co., Ltd. (China).

Cell culture. The HT-29 colon carcinoma cell line was cultured in RPMI-1640 medium supplemented with $10 \%$ fetal bovine serum plus ampicillin and streptomycin routinely, and incubated in $5 \% \mathrm{CO}_{2}$ at $37^{\circ} \mathrm{C}$.

TRAIL and CPT-11-mediated toxicity. Cell viability was measured by the SRB method (10). Briefly, exponentially growing tumor cells were seeded in a 96-well plate $\left(1 \times 10^{4} /\right.$ well $)$. Cells were incubated without treatment for 24 and $72 \mathrm{~h}$, respectively, in a negative control group 1 and 2 . Adherent cell cultures were fixed in situ by addition of $45 \mu \mathrm{l}$ of cold $50 \%$ $(\mathrm{w} / \mathrm{v})$ trichloroacetic acid (TCA) and were kept for $60 \mathrm{~min}$ at $4^{\circ} \mathrm{C}$. The supernatant was then discarded, and the plates were washed 5 times with distilled water and air dried. In the TRAIL or CPT-11 alone group (cells treated with TRAIL or CPT-11 alone), cells were incubated for $24 \mathrm{~h}$, and then TRAIL or CPT-11 was added to each well, respectively. The final concentrations of TRAIL were $0.001,0.01,0.1,1$ and $10 \mu \mathrm{g} / \mathrm{ml}$, respectively. The final concentrations of CPT-11 were $0.1,0.5$, 1,5 and $10 \mu \mathrm{g} / \mathrm{ml}$, respectively. The cytotoxic effect was evaluated $48 \mathrm{~h}$ after drug challenge. Briefly, adherent cell cultures were fixed in situ by addition of $45 \mu \mathrm{l}$ of cold $50 \%$ (w/v) TCA and were kept for $60 \mathrm{~min}$ at $4^{\circ} \mathrm{C}$. The supernatant was then discarded, and the plates were washed 5 times with distilled water and air dried. SRB solution $(0.4 \% \mathrm{w} / \mathrm{v}$ in $1 \%$ acetic acid) was added and the cells were allowed to stain for $10 \mathrm{~min}$ at room temperature. Unbound SRB was removed by washing 3 times with $1 \%$ acetic acid. The plates were then air dried. Bound stain was dissolved with unbuffered $10 \mathrm{mM}$ Tris base [tris(hydroxymethyl)aminomethane]. The absorbance values of the solution in each well were measured at $490 \mathrm{~nm}$ using a microplate reader. Cell viability was measured by the formula: If $\mathrm{Ti} \geq \mathrm{Tz}$, cell viability $(\%)=[(\mathrm{Ti}-\mathrm{Tz}) /(\mathrm{C}-\mathrm{Tz})] \times 100 ;$ If $\mathrm{Ti}<\mathrm{Tz}$, cell viability $(\%)=[(\mathrm{Ti}-\mathrm{Tz}) / \mathrm{Tz}] \times 100 .(\mathrm{Ti}$, absorbance of the wells treated with TRAIL or CPT-11; Tz, absorbance of the wells in negative control 1; C, absorbance of the wells in negative control 2). All SRB experiments were performed in triplicate and repeated at least 3 times.
The concentrations of reagents that induced a $50 \%$ reduction in cell viability $\left(\mathrm{IC}_{50}\right)$ were determined from curves of reagent concentration vs. cell viability at $48 \mathrm{~h}$ of incubation for the cell line analyzed. The sensitivity of cells to the drug was evaluated by the value of $\mathrm{IC}_{50} . \mathrm{IC}_{50}<10 \mu \mathrm{g} / \mathrm{ml}$, indicated that the cells were sensitive to the drug, while $\mathrm{IC}_{50} \geq 10 \mu \mathrm{g} / \mathrm{ml}$, indicated that the cells were relatively resistant to the drug (11).

Combination of TRAIL and CPT-11-mediated toxicity. According to the effect of TRAIL and CPT-11 treatment alone on cell viability, the concentrations of the combination of TRAIL and CPT-11 were chosen as follows: TRAIL (0.1, 1 and $10 \mu \mathrm{g} / \mathrm{ml}$, respectively), CPT- $11(1,5$ and $10 \mu \mathrm{g} / \mathrm{ml}$, respectively). Cell viability was then assessed by SRB assay. Negative control group 1, negative control group 2, TRAIL alone group, CPT-11 alone group and combination group (cells treated with TRAIL and CPT-11) were designed for this experiment.

Evaluation of synergistic effect. The synergistic effect of the combination of TRAIL and CPT-11 was analyzed by the Webb coefficient (12). Predicted cell viability (c) was calculated according to the equation $\mathrm{c}=\mathrm{a} \times \mathrm{b} / 100$, where $\mathrm{a}$ and $\mathrm{b}$ indicated cell viability with single agents. Synergism in drug interaction was indicated by observed cell viability of $\leq 70 \%$ of the predicted cell viability (11). According to the results of synergetic effect, the optimum concentrations of $0.1 \mu \mathrm{g} / \mathrm{ml}$ TRAIL and $5 \mu \mathrm{g} / \mathrm{ml} \mathrm{CPT-11} \mathrm{were} \mathrm{chosen} \mathrm{for} \mathrm{later} \mathrm{experiments}$ in vitro.

DNA ladder assay. For detection of apoptosis by the DNA fragmentation assay, $2 \times 10^{6}$ cells were plated into culture dishes $24 \mathrm{~h}$ prior to drug treatment. Following treatment with TRAIL or CPT-11 for 48 h, HT-29 cells were washed with phosphate-buffered saline (PBS) and harvested. Cells were then resuspended in $0.5 \mathrm{ml}$ of lysis buffer for $10 \mathrm{~min}$ at room temperature. After centrifugation at $12,000 \mathrm{rpm}$ at room temperature for $5 \mathrm{~min}$, the supernatant was transferred to a new Eppendorf tube and equal volumes of isopropanol were added, before centrifuging at 2,000 rpm at room temperature for $30 \mathrm{sec}$. DNA was acquired by centrifugation of the samples, washed, dried and dissolved in loading buffer, and separated by electrophoresis during $90 \mathrm{~min}$ at $60 \mathrm{~V}$ on $2 \%$ agarose gels, containing ethidium bromide (EB). Bands were visualised under ultraviolet light.

Flow cytometry analysis of apoptosis. To confirm that TRAILand CPT-11- mediated cell death occurs by apoptosis, we employed flow cytometry and determined the percentage of specific apoptotic cells. Apoptosis was quantified using the Annexin V-FITC apoptosis detection kit according to the manufacturer's instructions. Briefly, exponentially growing tumor cells were first digested with $0.25 \%$ trypsin and counted. They were then diluted to a final concentration of $1 \times 10^{5}$ cells $/ \mathrm{ml}$ and inoculated into a culture dish at $10 \mathrm{ml} / \mathrm{dish}$. When 50-60\% confluency was reached, cells incubated with $5 \mu \mathrm{g} / \mathrm{ml}$ CPT- 11 or $0.1 \mu \mathrm{g} / \mathrm{ml}$ TRAIL alone or with the combination of both for $48 \mathrm{~h}$ were harvested by trypsin release, washed twice with cold PBS, and permeabilized with 70\% ethanol in PBS for $30 \mathrm{~min}$. Then they were resuspended in Annexin V binding buffer. FITC-conjugated Annexin V $(1 \mu \mathrm{g} / \mathrm{ml})$ and propidium 
iodide $(50 \mu \mathrm{g} / \mathrm{ml})$ were added to the cells and incubated for $15 \mathrm{~min}$ at room temperature in the dark before flow cytometry analysis. The samples were detected using an Elite-ESP flow cytometer (Beckman-Coulter, USA). A minimum of $10^{4}$ cells were analyzed in each sample. All experiments were repeated at least 3 times.

Reverse transcription polymerase chain reaction ( $R T-P C R)$. Total-RNA was extracted from cells using TRIzol reagent. The RNA was then quantified spectrophotometrically. RT-PCR was run using One-Step RT-PCR kit. The primers for DR4, DR5 and glyceraldehyde-3-phosphate dehydrogenase (GAPDH) were synthesized by Shanghai Genebase Gene-Tech Co., Ltd. (China). GAPDH was used as internal control primer. The upstream primers of DR4, DR5 and GAPDH were, 5'-CTGAGCAACGCAGACTCGCTGTCCAC-3', 5'-GCCTC ATGGACAATGAGATAAAGGTGGCT-3' and 5'-ACCAC AGTCCATGCCATCAC-3', respectively. The downstream primers of DR4, DR5 and GAPDH were, 5'-ACAGCATCAG AGTCTCAGTGGGGTCAGC-3', 5'-CCAAATCTCAAAGTA CGCACAAACGG-3' and 5'-TCCACCACCCTGTTGCTG TA-3', respectively. The PCR products were a 202-bp fragment for DR4, a 220-bp fragment for DR5, and a 485-bp fragment for GAPDH, respectively.

PCR was performed in a $25 \mu \mathrm{l}$ reaction volume. PCR cycling conditions of DR4 were as follows: an initial denaturing step at $94^{\circ} \mathrm{C}$ for $2 \mathrm{~min}, 30$ cycles repeating a denaturation step of $94^{\circ} \mathrm{C}$ for $10 \mathrm{sec}$, followed by an optimized annealing temperature of $59^{\circ} \mathrm{C}$ for $10 \mathrm{sec}$, and a final elongation step at $72^{\circ} \mathrm{C}$ for $20 \mathrm{sec}$. PCR cycling conditions of DR5 were as follows: an initial denaturing step at $95^{\circ} \mathrm{C}$ for $2 \mathrm{~min}, 30$ cycles repeating $94^{\circ} \mathrm{C}$ for $10 \mathrm{sec}, 52^{\circ} \mathrm{C}$ for $10 \mathrm{sec}$ and $72^{\circ} \mathrm{C}$ for $20 \mathrm{sec}$.

Amplified products of DR4, DR5 and GAPDH were separated by $1.5 \%$ agarose gel electrophoresis in EB stained and viewed under ultraviolet light. The electrophoresis images were obtained and the DR4, DR5 and GAPDH band integrated optical density values were analyzed using the Bio-Rad image system. Semiquantitative analysis of DR4 and DR5 mRNA was performed by comparison to GAPDH.

Western blot analysis. Cells incubated with $5 \mu \mathrm{g} / \mathrm{ml}$ CPT-11 or $0.1 \mu \mathrm{g} / \mathrm{ml}$ TRAIL alone or in combination for $48 \mathrm{~h}$ were lysed in lysis buffer. Protein content of the supernatant was measured using the bicinchoninic acid (BCA) method. Cell lysate protein $(25 \mu \mathrm{g})$ was separated by SDS-PAGE using a Trisglycine system and then gels were electroblotted onto PVDF membranes for $1.5 \mathrm{~h}$. The membranes were then incubated with $5 \%$ non-fat dry milk in PBS for $1 \mathrm{~h}$ for blocking nonspecific binding sites, and then incubated with the appropriate primary antibody concentration (1:400 dilution for caspase-9 and Bax, and $1: 2,000$ for $\beta$-actin) for $1 \mathrm{~h}$ at $37^{\circ} \mathrm{C}$ in $5 \%$ non-fat dry milk. Membranes were subsequently rinsed in PBS, and then incubated for $1 \mathrm{~h}$ at $37^{\circ} \mathrm{C}$ with secondary antibody (horseradish peroxidase conjugated anti-mouse IgG at 1:2,000 dilution). Following incubation, membranes were rinsed and blots were visualized by incubation with ECL detection reagents. Signal density was obtained by scanning exposed X-ray films on a Bio-Rad imaging system. Normalized density was obtained by dividing the rough density values of a sample band over loading control band ( $\beta$-actin).
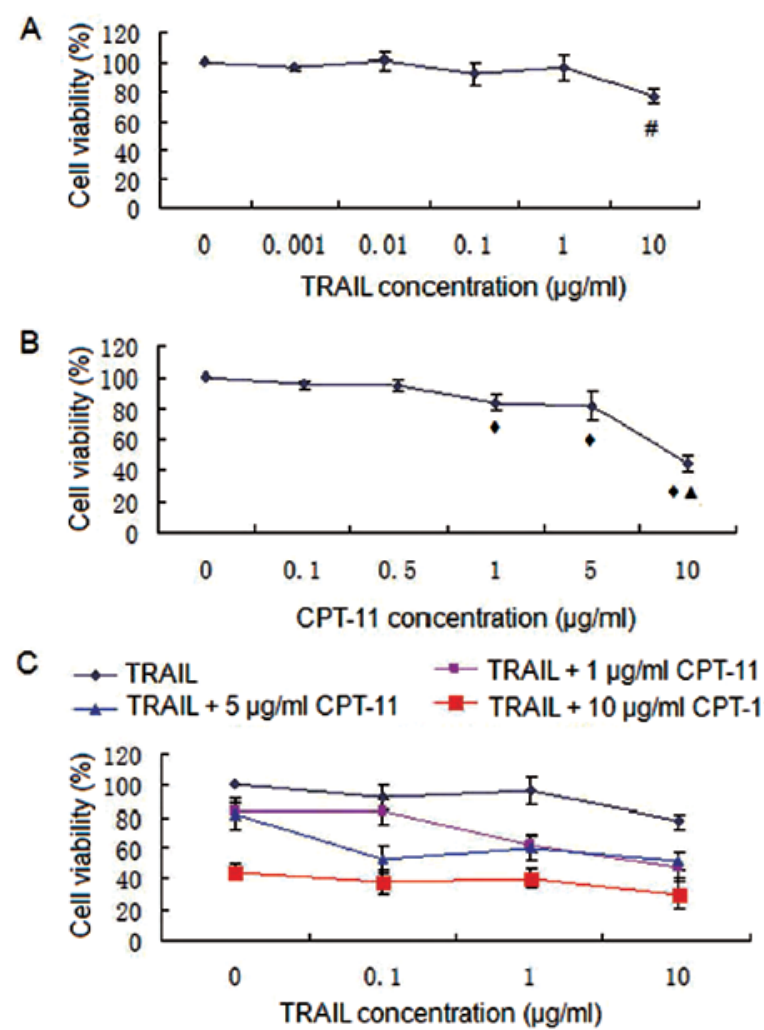

Figure 1. SRB assay. (A) TRAIL treatment; (B) CPT-11 treatment; (C) combination treatment. ${ }^{\#} \mathrm{P}<0.05$ compared with $0,0.01,0.01,0.1$ and $1 \mu \mathrm{g} / \mathrm{ml}$ TRAIL; ${ }^{\bullet} \mathrm{P}<0.05$ compared with $0,0.1$ and $0.5 \mu \mathrm{g} / \mathrm{ml} \mathrm{CPT}-11 ;{ }^{\wedge} \mathrm{P}<0.05$ compared with $0,0.1,0.5,1$ and $5 \mu \mathrm{g} / \mathrm{ml}$ CPT-11. TRAIL induced limited cell death, and there was significant negative correlation between cell viability and TRAIL concentration $(\mathrm{r}=-0.779, \mathrm{P}<0.05)$. $\mathrm{IC}_{50}$ was $>10 \mu \mathrm{g} / \mathrm{ml}$ suggesting that HT-29 cells were relatively resistant to TRAIL. CPT-11 induced cell death in a dose-dependent manner $(\mathrm{r}=-0.863, \mathrm{P}<0.05) . \mathrm{IC}_{50}$ was $<10 \mu \mathrm{g} / \mathrm{ml}$ suggesting that HT-29 cells were sensitive to CPT-11.

Combined effects on HT-29 xenograft on nude mice. All animal procedures were approved by the Animal Care and Scientific Committee of Sichuan University. Thirty-six HT-29 bearing nude mice were divided into 6 groups (6 mice/group); the control group, treated with normal saline; the TRAIL-5 mg/kg group, treated with TRAIL with a concentration of $5 \mathrm{mg} / \mathrm{mice}$ weight $(\mathrm{kg})$; the TRAIL-15 $\mathrm{mg} / \mathrm{kg}$ group, treated with TRAIL with a concentration of $15 \mathrm{mg} / \mathrm{mice}$ weight $(\mathrm{kg})$; the CPT-11$12.5 \mathrm{mg} / \mathrm{kg}$ group, treated with CPT-11 with a concentration of $12.5 \mathrm{mg} / \mathrm{mice}$ weight $(\mathrm{kg})$; the TRAIL-5 mg/kg + CPT-11$12.5 \mathrm{mg} / \mathrm{kg}$ group, treated with TRAIL with a concentration of $5 \mathrm{mg} /$ mice weight $(\mathrm{kg})$ and CPT-11 with a concentration of $12.5 \mathrm{mg} /$ mice weight $(\mathrm{kg})$; the TRAIL-15 mg/kg + CPT-11$12.5 \mathrm{mg} / \mathrm{kg}$ group, treated with TRAIL with a concentration of $15 \mathrm{mg} / \mathrm{mice}$ weight $(\mathrm{kg})$ and CPT-11 with a concentration of $12.5 \mathrm{mg} / \mathrm{mice}$ weight $(\mathrm{kg})$. Saline was injected through the tail vein 15 times in 15 days; TRAIL was injected through the tail vein 5 times in 5 days, and CPT-11 was injected into the peritoneal cavity 6 times in 6 days. The length, width, and weight of the tumor were measured using a slide caliper every 5 days. Tumor volume (TV) was estimated using the formula: $\mathrm{TV}\left(\mathrm{mm}^{3}\right)=\left(\right.$ width $^{2} \mathrm{x}$ length $) / 2$. Inhibitive rate of tumor was calculated using the formula: inhibitive rate of tumor $(\%)$ $=(1-$ average weight in treated group/average weight in control) x $100 \%$ (13). 
Table I. Analysis of the synergetic effect of TRAIL and CPT-11 on the cell viability of HT-29 cells.

\begin{tabular}{lccc}
\hline Group & $\begin{array}{c}\text { Concentration } \\
(\mu \mathrm{g} / \mathrm{ml})\end{array}$ & $\begin{array}{c}\text { Observed cell } \\
\text { viability }(\%)\end{array}$ & $\begin{array}{c}70 \% \text { estimated cell } \\
\text { viability }(70 \% \mathrm{c})\end{array}$ \\
\hline $\mathrm{T} 1$ & 10 & $77.46(\mathrm{a} 1)$ & \\
$\mathrm{T} 2$ & 1 & $96.42(\mathrm{a} 2)$ & \\
$\mathrm{T} 3$ & 0.1 & $92.45(\mathrm{a} 3)$ & \\
$\mathrm{C} 1$ & 10 & $44.28(\mathrm{~b} 1)$ & \\
$\mathrm{C} 2$ & 5 & $82.14(\mathrm{~b} 2)$ & 24.01 \\
$\mathrm{C} 3$ & 1 & $83.85(\mathrm{~b} 3)$ & 44.54 \\
$\mathrm{~T} 1+\mathrm{C} 1$ & & 30.19 & 45.47 \\
$\mathrm{~T} 1+\mathrm{C} 2$ & & 51.39 & 29.89 \\
$\mathrm{~T} 1+\mathrm{C} 3$ & & 47.72 & 55.44 \\
$\mathrm{~T} 2+\mathrm{C} 1$ & & 40.20 & 56.59 \\
$\mathrm{~T} 2+\mathrm{C} 2$ & & 59.96 & 40.94 \\
$\mathrm{~T} 2+\mathrm{C} 3$ & 62.25 & 53.15 \\
$\mathrm{~T} 3+\mathrm{C} 1$ & & 37.86 & 54.26 \\
$\mathrm{~T} 3+\mathrm{C} 2$ & $52.26^{\mathrm{a}}$ & $>0.05$ \\
$\mathrm{~T} 3+\mathrm{C} 3$ & 83.40 & $>0.05$ \\
\hline
\end{tabular}

Synergistic effect was analyzed by the Webb coefficient. Predicted cell viability $(\mathrm{c}, \%)$ was calculated according to the equation $\mathrm{c}=\mathrm{a} \mathrm{x} \mathrm{b} / 100$, where $\mathrm{a}$ and $\mathrm{b}$ indicate cell viability with single agents. Synergism in drug interaction was indicated by observed cell viability of $\leq 70 \%$ of the predicted cell viability. T,

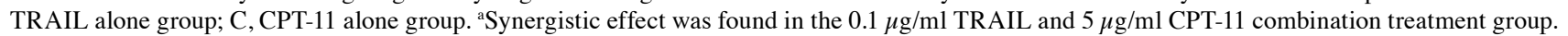

Statistical analysis. Results were expressed as the mean \pm standard deviation (SD) with the exception of the tumor inhibitive rate. Statistical comparisons of mean values were analyzed by one-way ANOVA, followed by the Student's t-test. Data of tumor inhibitive rate were analyzed using the Chi-square test. Linear correlation between cell viability and concentrations of CPT-11 or TRAIL was analyzed using SPSS 13.0 software. Synergetic effect was evaluated using the Webb coefficient. All P-values were 2-sided and $\mathrm{P}<0.05$ was considered to indicate statistically significant differences.

\section{Results}

SRB assay. Results of the SRB assay are shown in Fig. 1 and demonstrate that TRAIL induced limited cell death, and there was significant negative correlation between cell viability and TRAIL concentration $(\mathrm{r}=-0.779, \mathrm{P}<0.05) . \mathrm{IC}_{50}>10 \mu \mathrm{g} / \mathrm{ml}$ suggesting that HT-29 cells were relatively resistant to TRAIL. The cell viability of HT-29 cells treated with $10 \mu \mathrm{g} / \mathrm{ml}$ TRAIL was significantly higher than in $0,0.01,0.01,0.1$ and $1 \mu \mathrm{g} / \mathrm{ml}$ TRAIL groups (Fig. 1A). CPT-11 induced cell death in a dosedependent manner $(\mathrm{r}=-0.863, \mathrm{P}<0.05) . \mathrm{IC}_{50}$ was $<10 \mu \mathrm{g} / \mathrm{ml}$ suggesting that HT-29 cells were sensitive to CPT-11. The cell viability of HT-29 treated with $1 \mu \mathrm{g} / \mathrm{ml}$ CPT-11 was significantly higher than in $0,0.1$ and $0.5 \mu \mathrm{g} / \mathrm{ml} \mathrm{CPT}-11$ groups, and the cell viability of HT-29 cells treated with $10 \mu \mathrm{g} / \mathrm{ml} \mathrm{CPT-11}$ was higher than in $0,0.1,0.5,1$ and $5 \mu \mathrm{g} / \mathrm{ml} \mathrm{CPT-11} \mathrm{groups}$ (Fig. 1B). Webb coefficient analysis showed that only $0.1 \mu \mathrm{g} / \mathrm{ml}$ TRAIL combined with $5 \mu \mathrm{g} / \mathrm{ml}$ CPT-11 had a significant synergistic effect $(\mathrm{P}<0.05)$ (Fig. $1 \mathrm{C}$ and Table I).

DNA ladder assay and flow cytometry. DNA fragmentation was seen in the TRAIL and combined groups, but not in the other 2 groups (Fig. 2C). The apoptosis rates were 0.9, 17.5, 8.1 and $29.3 \%$, respectively, in the control, TRAIL alone, CPT-11 alone, and combined group. There were significant differences of apoptosis rates in the combined group vs. the other groups $(\mathrm{P}<0.05)$ (Fig. 2A and $\mathrm{B})$.

DR5 and DR4 mRNA expression. Compared with the control or TRAIL alone or CPT-11 alone groups, the combination of TRAIL and CPT-11 significantly upregulated the expression of DR5 mRNA in HT-29 cells (Fig. 3A and C), whereas DR4 mRNA in HT-29 cells showed no significant difference among the groups (Fig. 3B and D).

Bax and caspase-9 protein expression. As shown in Fig. 4, the combination treatment of TRAIL and CPT-11 significantly upregulated Bax and caspase-9 proteins $(\mathrm{P}<0.05)$.

Tumor growth curves and inhibitive rates of tumor growth. The treatment began on Day 10 after the injection of tumor cells. The tumor volumes were recorded every 5 days and the tumor growth curves were depicted. The tumor growth curves and inhibitive rates are shown in Figs. 5 and 6, respectively. The results show that the 2 combined treatment groups could inhibit the tumor growth significantly compared with the other groups $(\mathrm{P}<0.05)$.

\section{Discussion}

TRAIL induced apoptotic cell death in a variety of tumorigenic or transformed cell lines but not in normal cells (14). The selective killing of tumor cells by TRAIL has made TRAIL receptors attractive targets for cancer treatment. In preclinical models, recombinant soluble TRAIL demonstrated 

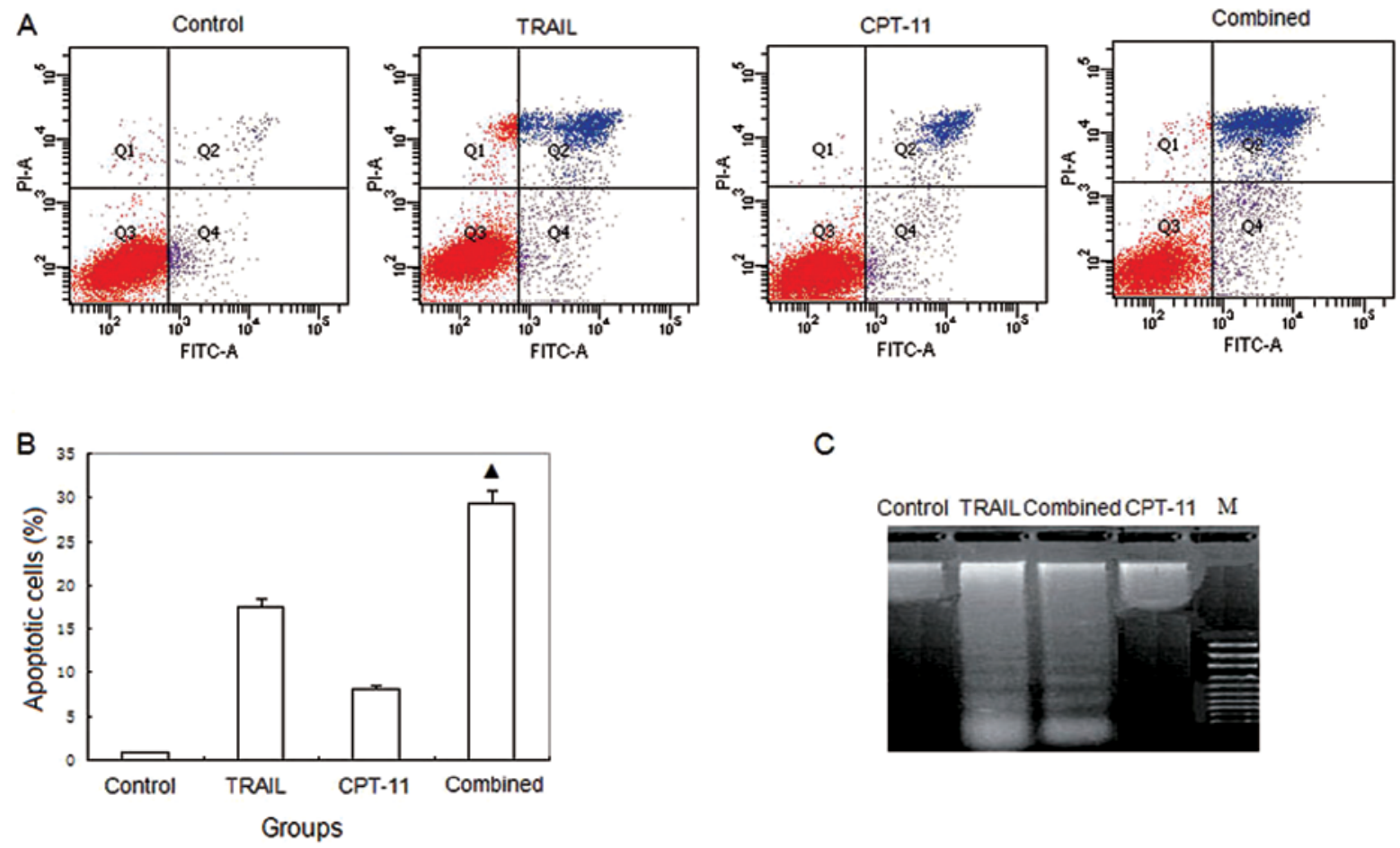

C

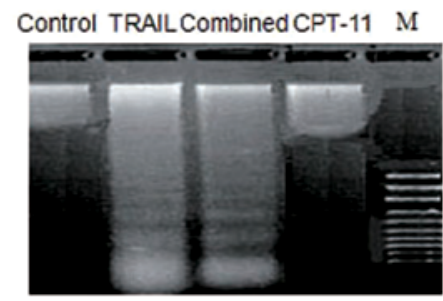

Figure 2. Flow cytometry and DNA ladder. (A) Flow cytometry; (B) histogram of flow cytometry; (C) DNA ladder. Control, HT-29 treated with saline; TRAIL, HT-29 treated with $0.1 \mu \mathrm{g} / \mathrm{ml}$ TRAIL; CPT-11, HT-29 treated with $5 \mu \mathrm{g} / \mathrm{ml} \mathrm{CPT-11;} \mathrm{combined,} \mathrm{HT-29} \mathrm{treated} \mathrm{with} 0.1 \mu \mathrm{g} / \mathrm{ml}$ TRAIL and $5 \mu \mathrm{g} / \mathrm{ml}$ CPT-11; M, marker. The apoptosis rates were $0.9,17.5,8.1$ and $29.3 \%$, respectively in the control, TRAIL, CPT-11, and combined group. ${ }^{\wedge} \mathrm{P}<0.05$ compared with the control, TRAIL and CPT-11 groups. DNA fragmentation was seen in the TRAIL and combined groups, but not in the other 2 groups.

A
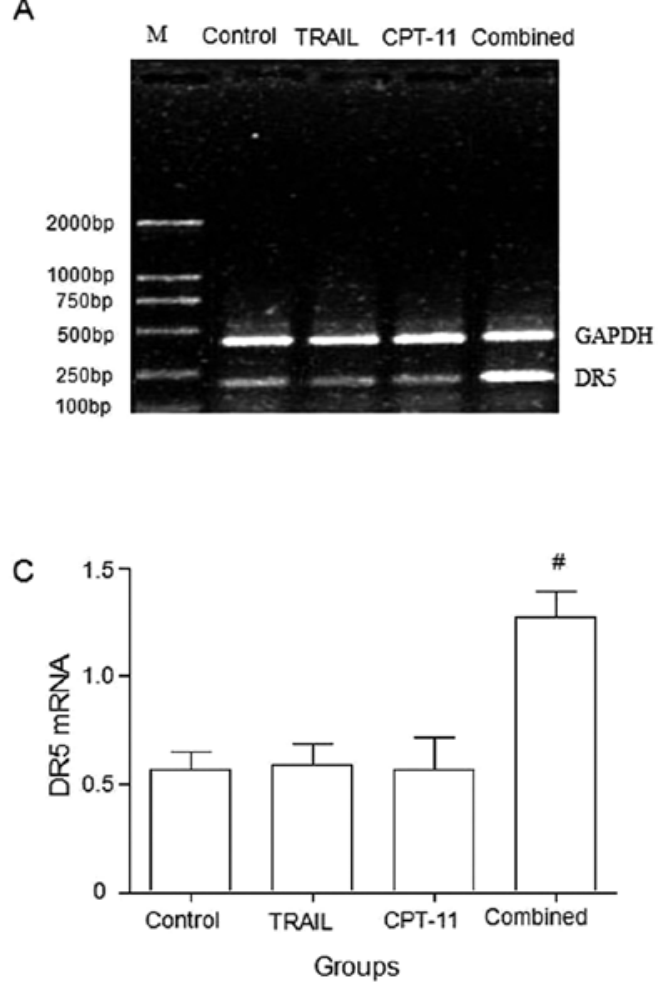

B
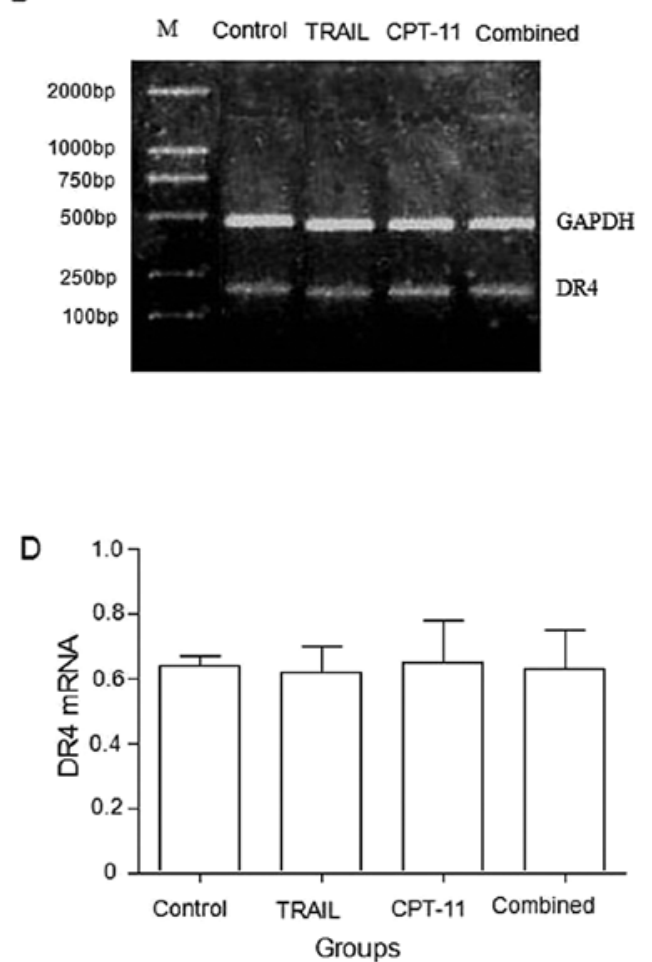

Figure 3. RT-PCR of DR5 and DR4 mRNA expression. (A) DR5 mRNA expression; (B) DR4 mRNA expression; (C) histogram of DR5 mRNA expression; (D) histogram of DR4 mRNA expression. Control, HT-29 treated with saline; TRAIL, HT-29 treated with $0.1 \mu \mathrm{g} / \mathrm{ml}$ TRAIL; CPT-11, HT-29 treated with $5 \mu \mathrm{g} / \mathrm{ml}$ CPT-11; combined, HT-29 treated with $0.1 \mu \mathrm{g} / \mathrm{ml}$ TRAIL and $5 \mu \mathrm{g} / \mathrm{ml}$ CPT-11; M, marker. ${ }^{~} \mathrm{P}<0.05$ compared with the control, TRAIL, and CPT-11 groups. 


\section{A control TRAIL CPT-11 Combined}
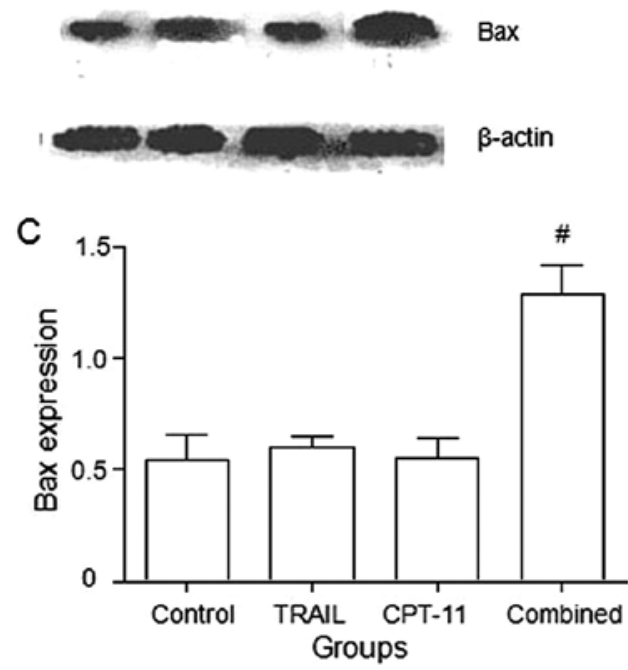

B

Control TRAIL CPT-11 Combined
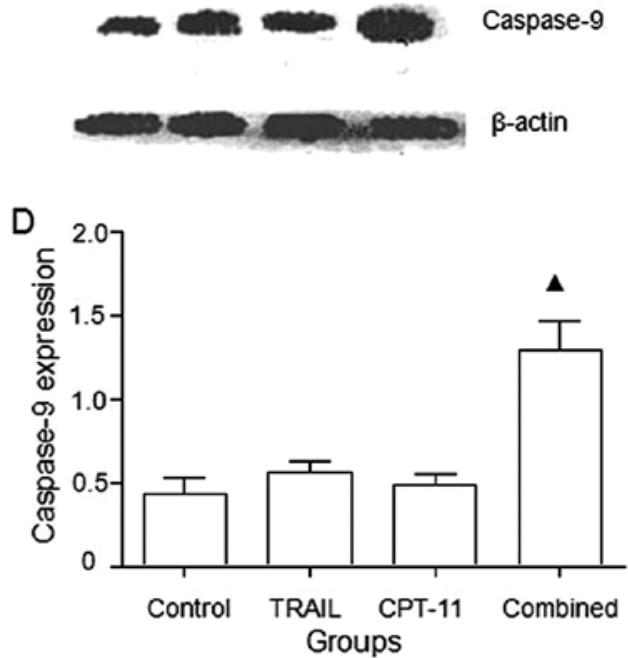

Figure 4. Bax and caspase-9 protein expression. (A) Bax expression; (B) caspase-9 expression; (C) histogram of Bax expression; (D) histogram of caspase-9 expression. Control, HT-29 treated with saline; TRAIL, HT-29 treated with $0.1 \mu \mathrm{g} / \mathrm{ml}$ TRAIL; CPT-11, HT-29 treated with $5 \mu \mathrm{g} / \mathrm{ml}$ CPT-11; combined, HT-29 treated with $0.1 \mu \mathrm{g} / \mathrm{ml}$ TRAIL and $5 \mu \mathrm{g} / \mathrm{ml} \mathrm{CPT}-11 .{ }^{~} \mathrm{P}<0.05$ compared with the control, TRAIL and CPT-11 groups. ${ }^{\wedge} \mathrm{P}<0.05$ compared with the control, TRAIL and CPT-11 groups.

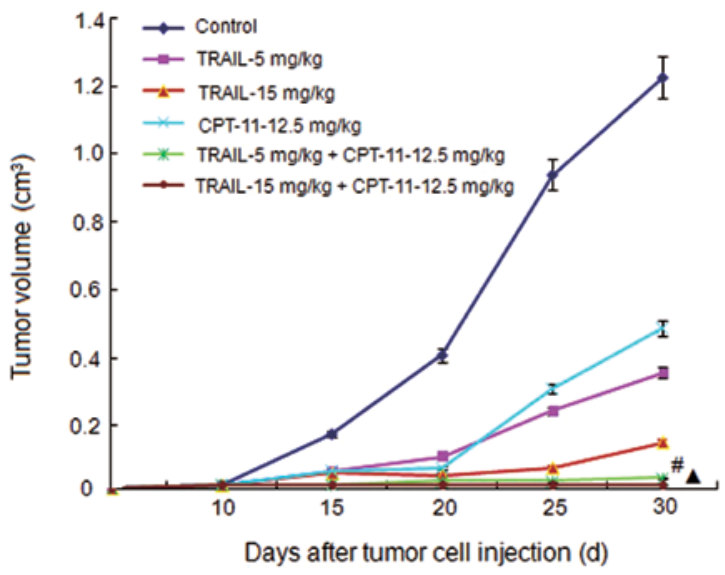

Figure 5. Tumor growth curves. Control, mice treated with normal saline; TRAIL-5 mg/kg, mice treated with TRAIL with a concentration of $5 \mathrm{mg} / \mathrm{mouse}$ weight $(\mathrm{kg})$; TRAIL- $15 \mathrm{mg} / \mathrm{kg}$, mice treated with TRAIL with a concentration of $15 \mathrm{mg} / \mathrm{mouse}$ weight $(\mathrm{kg})$; CPT-11-12.5 mg/kg, mice treated with CPT-11 with a concentration of $12.5 \mathrm{mg} /$ mouse weight $(\mathrm{kg})$; TRAIL- $5 \mathrm{mg} / \mathrm{kg}+\mathrm{CPT}$ $11-12.5 \mathrm{mg} / \mathrm{kg}$, mice treated with TRAIL with a concentration of $5 \mathrm{mg} / \mathrm{mouse}$ weight $(\mathrm{kg})$ and CPT-11 with a concentration of $12.5 \mathrm{mg} / \mathrm{mouse}$ weight $(\mathrm{kg})$; TRAIL-15 mg/kg + CPT-11-12.5 mg/kg, mice treated with TRAIL with a concentration of $15 \mathrm{mg} / \mathrm{mouse}$ weight $(\mathrm{kg})$ and CPT-11 with a concentration of $12.5 \mathrm{mg} / \mathrm{mouse}$ weight $(\mathrm{kg}) .{ }^{\#} \mathrm{P}<0.05$ compared with the control, TRAIL, and CPT-11 groups. ${ }^{\wedge} \mathrm{P}<0.05$ compared with the control, TRAIL, and CPT-11 groups.

notable anticancer activity $(15,16)$. However, an increasing number of studies have demonstrated TRAIL resistance in primary human tumor cells especially in those of solid tumor entities (17). Thus, novel treatment strategies are urgently required to overcome this resistance in tumor cells. Several reports have described the ability of subtoxic concentrations of chemotherapeutic drugs to sensitize tumor cells that are resistant to TRAIL (18). The antitumor properties of TRAIL can be significantly enhanced when used in combination with

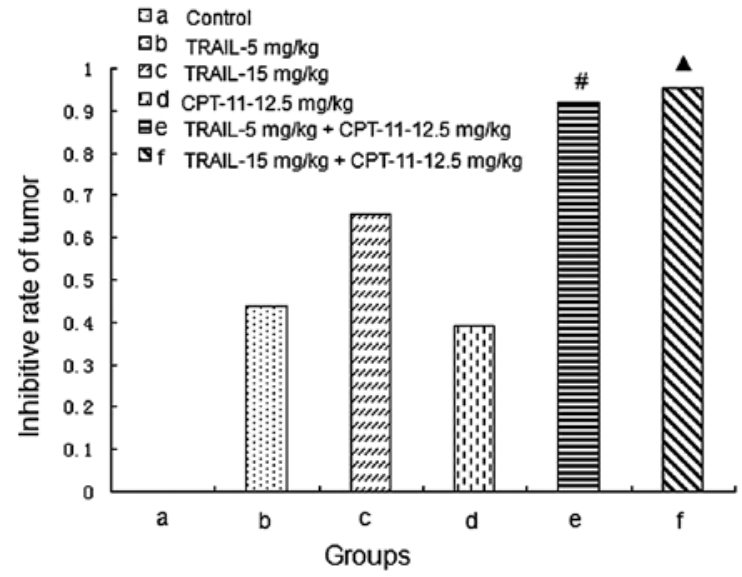

Figure 6. Inhibitive rates of tumor growth. (a) Control, mice treated with normal saline; (b) TRAIL-5 mg/kg, mice treated with TRAIL with a concentration of $5 \mathrm{mg} / \mathrm{mouse}$ weight ( $\mathrm{kg}$ ); (c) TRAIL-15 mg/kg, mice treated with TRAIL with a concentration of $15 \mathrm{mg} / \mathrm{mouse}$ weight $(\mathrm{kg})$; (d) CPT-11$12.5 \mathrm{mg} / \mathrm{kg}$, mice treated with CPT-11 with a concentration of $12.5 \mathrm{mg} / \mathrm{mouse}$ weight (kg); (e) TRAIL-5 mg/kg + CPT-11-12.5 mg/kg, mice treated with TRAIL with a concentration of $5 \mathrm{mg} / \mathrm{mouse}$ weight $(\mathrm{kg})$ and CPT-11 with a concentration of $12.5 \mathrm{mg} / \mathrm{mouse}$ weight (kg); (f) TRAIL-15 mg/kg + CPT-11$12.5 \mathrm{mg} / \mathrm{kg}$, mice treated with TRAIL with a concentration of $15 \mathrm{mg} / \mathrm{mouse}$ weight $(\mathrm{kg})$ and CPT-11 with a concentration of $12.5 \mathrm{mg} / \mathrm{mouse}$ weight $(\mathrm{kg})$. ${ }^{\#} \mathrm{P}<0.05$ compared with the control, TRAIL, and CPT-11 groups. ${ }^{\wedge} \mathrm{P}<0.05$ compared with the control, TRAIL, and CPT-11 groups.

chemotherapy, as has been demonstrated in many studies using different tumor cell lines and mouse models (15).

In the present study, we focused on the synergistic effects of low-dose CPT-11 and TRAIL on the HT-29 TRAIL resistant colon cancer cell line. The SRB assay demonstrated that HT-29 cells were relatively resistant to TRAIL and sensitive to CPT-11. The antitumor effects of TRAIL could be significantly enhanced by a low-dose of CPT-11 on HT-29 cells. The DNA ladder assay and flow cytometry confirmed that low-dose 
CPT-11 could significantly enhance the apoptosis induction effects of TRAIL on HT-29 cells.

Previous studies showed that chemotherapeutic agents could increase the expressions of DR4 and DR5 in tumor cells (19). The upregulation of DR4 and DR5 enhanced the responsiveness of cells to TRAIL $(20,21)$ and cell death was enhanced when these agents were combined with TRAIL (19). Our data showed that the combination of TRAIL and CPT-11 could upregulate the expression of DR5 mRNA in HT-29 cells, whereas DR4 mRNA in HT-29 cells showed no significant difference among the groups.

TRAIL-induced apoptosis appears to require expression of one or both of its death domain containing receptors DR4 or DR5 (14). In addition, DR4 and DR5 actively promote apoptosis upon TRAIL binding (22). Although DR4, DR5, DcR1 and OPG show similar affinities for TRAIL at $4^{\circ} \mathrm{C}$, their rankordered affinities are substantially different at $37^{\circ} \mathrm{C}$ with DR5 having the highest affinity (14). The findings of Wen et al (23) indicate that etoposide, Ara-C, or doxorubicin that are sensitive to TRAIL-induced apoptosis in human acute leukemia cells are associated with upregulation of DR5 but not DR4. In addition, some results also showed that chemotherapeutic agents could augment TRAIL-induced apoptosis by upregulating DR5 $(24,25)$. Collectively, our data indicate that the synergistic apoptotic effect of CPT-11 and TRAIL is mediated by a transcriptional induction of DR5.

Apoptosis is now understood to involve 2 major signaling pathways, one initiated by DNA damage and one initiated by death receptors (DRs) (26). The synergistic cytotoxic effect of genotoxic drugs and TRAIL was proposed to be p53 dependent $(18,20)$. The genes involved in p53-mediated apoptosis include Bax $(27,28)$ and caspase-9 $(28,29)$. Bax is essential for death receptor-mediated apoptosis in cancer cells. LeBlanc et al (30) found that HCT116 human colon carcinoma cells are completely dependent upon Bax for apoptosis induction by death-receptor ligands. Caspases play a critical role in the execution of apoptosis (31). Caspase-9, the major initiator caspase identified to date (32), is an essential downstream component of p53-induced apoptosis. In addition, caspase-9 is involved in death induced by cytotoxic agents (33). Some results showed that overexpression of caspase- 9 alone induced apoptosis in U-87MG glioma cells (28). Our results showed that the combination treatment of TRAIL and CPT-11 could significantly upregulate Bax and caspase- 9 proteins. These results indicate that anticancer drugs increase the ability of TRAIL to trigger a caspase-dependent cell apoptosis, in accordance with the results of Lacour et al (18).

The in vivo experiments also showed that the antitumor effects of TRAIL could be enhanced significantly by a lowdose of CPT-11. The 2 combined groups yielded very strong effects and tumor growth was thoroughly inhibited. In this study, the dose of CPT-11 used was $12.5 \mathrm{mg} / \mathrm{kg}$ which was lower than other studies $(25$ or $50 \mathrm{mg} / \mathrm{kg})(24,34)$. However, the inhibitive rates of tumor in the combined groups were still notable. TRAIL and CPT-11 showed significant synergistic effects and could be a promising treatment for TRAIL resistant HT-29 colon carcinoma.

In conclusion, the antitumor effect of TRAIL can be significantly enhanced by low-dose CPT-11 on TRAIL-resistant HT-29 cells both in vitro and in vivo. The synergistic apoptotic effect of CPT-11 and TRAIL was proposed to be mediated by upregulating DR5 mRNA expression and increasing expression of Bax and caspase- 9 proteins. The data suggest that the combination of TRAIL with low-dose CPT-11 may be a promising therapeutic approach for HT-29 colon carcinoma.

\section{Acknowledgements}

This study was supported by grants from the National Natural Scientific Foundation of China (no. 81070313).

\section{References}

1. Oosterling SJ, van der Bij GJ, Bogels M, ten Raa S, Post JA, Meijer GA, Beelen RH and van Egmond M: Anti-betal integrin antibody reduces surgery-induced adhesion of colon carcinoma cells to traumatized peritoneal surfaces. Ann Surg 247: 85-94, 2008.

2. Hennebelle I, Terret C, Chatelut E, Bugat R, Canal P and Guichard S: Characterization of CPT-11 converting carboxylesterase activity in colon tumor and normal tissues: comparison with p-nitro-phenylacetate converting carboxylesterase activity. Anticancer Drugs 11: 465-470, 2000.

3. Saetern AM, Brandl M, Bakkelund WH and Sveinbjornsson B: Cytotoxic effect of different camptothecin formulations on human colon carcinoma in vitro. Anticancer Drugs 15: 899-906, 2004.

4. Sanlioglu AD, Dirice E, Elpek O, Korcum AF, Ozdogan M, Suleymanlar I, Balci MK, Griffith TS and Sanlioglu S: High TRAIL death receptor 4 and decoy receptor 2 expression correlates with significant cell death in pancreatic ductal adenocarcinoma patients. Pancreas 38: 154-160, 2009.

5. Ashkenazi A, Holland P and Eckhardt SG: Ligand-based targeting of apoptosis in cancer: the potential of recombinant human apoptosis ligand 2/Tumor necrosis factor-related apoptosis-inducing ligand (rhApo2L/TRAIL). J Clin Oncol 26: 3621-3630, 2008.

6. Yoo J, Park SS and Lee YJ: Pretreatment of docetaxel enhances TRAIL-mediated apoptosis in prostate cancer cells. J Cell Biochem 104: 1636-1646, 2008.

7. Oliver PG, LoBuglio AF, Zinn KR, Kim H, Nan L, Zhou T, Wang $\mathrm{W}$ and Buchsbaum DJ: Treatment of human colon cancer xenografts with TRA-8 anti-death receptor 5 antibody alone or in combination with CPT-11. Clin Cancer Res 14: 2180-2189, 2008.

8. Ravi R, Jain AJ, Schulick RD, Pham V, Prouser TS, Allen H, Mayer EG, Yu H, Pardoll DM, Ashkenazi A and Bedi A: Elimination of hepatic metastases of colon cancer cells via p53-independent cross-talk between irinotecan and Apo2 ligand/ TRAIL. Cancer Res 64: 9105-9114, 2004

9. Sugamura K, Gibbs JF, Belicha-Villanueva A, Andrews C, Repasky EA and Hylander BL: Synergism of CPT-11 and Apo2L/ TRAIL against two differentially sensitive human colon tumor xenografts. Oncology 74: 188-197, 2008.

10. Zhou W, Hu J, Tang H, Wang D, Huang X, He C and Zhu H Small interfering RNA targeting mcl-1 enhances proteasome inhibitor-induced apoptosis in various solid malignant tumors. BMC Cancer 11: 485, 2011.

11. Cui DD, Huang Y, Mao SH, Chen SC, Qiu M, Ji LL and Yi C: Synergistic antitumor effect of TRAIL and adriamycin on the human breast cancer cell line MCF-7. Braz J Med Biol Res 42: 854-862, 2009.

12. Yeh YA, Herenyiova M and Weber G: Quercetin: synergistic action with carboxyamidotriazole in human breast carcinoma cells. Life Sci 57: 1285-1292, 1995.

13. Liu B, Peng XC, Zheng XL, Wang J and Qin YW: MiR-126 restoration down-regulate VEGF and inhibit the growth of lung cancer cell lines in vitro and in vivo. Lung Cancer 66: 169-175, 2009.

14. Truneh A, Sharma S, Silverman C, Khandekar S, Reddy MP, Deen KC, McLaughlin MM, Srinivasula SM, Livi GP, Marshall LA, et al: Temperature-sensitive differential affinity of TRAIL for its receptors. DR5 is the highest affinity receptor. J Biol Chem 275: 23319-23325, 2000.

15. Kruyt FA: TRAIL and cancer therapy. Cancer Lett 263: 14-25, 2008.

16. Johnstone RW, Frew AJ and Smyth MJ: The TRAIL apoptotic pathway in cancer onset, progression and therapy. Nat Rev Cancer 8: 782-798, 2008. 
17. Koschny R, Walczak $H$ and Ganten TM: The promise of TRAIL-potential and risks of a novel anticancer therapy. J Mol Med 85: 923-935, 2007.

18. Lacour S, Hammann A, Wotawa A, Corcos L, Solary E and Dimanche-Boitrel MT: Anticancer agents sensitize tumor cells to tumor necrosis factor-related apoptosis-inducing ligand-mediated caspase-8 activation and apoptosis. Cancer Res 61: 1645-1651, 2001.

19. Henson ES, Johnston JB and Gibson SB: The role of TRAIL death receptors in the treatment of hematological malignancies. Leuk Lymphoma 49: 27-35, 2008.

20. Srivastava RK: TRAIL/Apo-2L: mechanisms and clinical applications in cancer. Neoplasia 3: 535-546, 2001.

21. Singh TR, Shankar S, Chen X, Asim M and Srivastava RK: Synergistic interactions of chemotherapeutic drugs and tumor necrosis factor-related apoptosis-inducing ligand/Apo-2 ligand on apoptosis and on regression of breast carcinoma in vivo. Cancer Res 63: 5390-5400, 2003.

22. McDonald ER III, Chui PC, Martelli PF, Dicker DT and El-Deiry WS: Death domain mutagenesis of KILLER/DR5 reveals residues critical for apoptotic signaling. J Biol Chem 276: 14939-14945, 2001

23. Wen J, Ramadevi N, Nguyen D, Perkins C, Worthington E and Bhalla K: Antileukemic drugs increase death receptor 5 levels and enhance Apo-2L-induced apoptosis of human acute leukemia cells. Blood 96: 3900-3906, 2000.

24. Naka T, Sugamura K, Hylander BL, Widmer MB, Rustum YM and Repasky EA: Effects of tumor necrosis factor-related apoptosis-inducing ligand alone and in combination with chemotherapeutic agents on patients' colon tumors grown in SCID mice. Cancer Res 62: 5800-5806, 2002.

25. Nagane M, Pan G, Weddle JJ, Dixit VM, Cavenee WK and Huang HJ: Increased death receptor 5 expression by chemotherapeutic agents in human gliomas causes synergistic cytotoxicity with tumor necrosis factor-related apoptosis-inducing ligand in vitro and in vivo. Cancer Res 60: 847-853, 2000.
26. Liu W, Bodle E, Chen JY, Gao M, Rosen GD and Broaddus VC: Tumor necrosis factor-related apoptosis-inducing ligand and chemotherapy cooperate to induce apoptosis in mesothelioma cell lines. Am J Respir Cell Mol Biol 25: 111-118, 2001.

27. Miyashita T and Reed JC: Tumor suppressor p53 is a direct transcriptional activator of the human bax gene. Cell 80: 293-299, 1995.

28. Shinoura N, Sakurai S, Asai A, Kirino T and Hamada H: Caspase-9 transduction overrides the resistance mechanism against p53-mediated apoptosis in U-87MG glioma cells. Neurosurgery 49: 177-1877, 2001.

29. Soengas MS, Alarcon RM, Yoshida H, Giaccia AJ, Hakem R, Mak TW and Lowe SW: Apaf-1 and caspase-9 in p53-dependent apoptosis and tumor inhibition. Science 284: 156-159, 1999.

30. LeBlanc H, Lawrence D, Varfolomeev E, Totpal K, Morlan J, Schow P, Fong S, Schwall R, Sinicropi D and Ashkenazi A: Tumor-cell resistance to death receptor-induced apoptosis through mutational inactivation of the proapoptotic Bcl-2 homolog Bax. Nat Med 8: 274-281, 2002.

31. Nunez G, Benedict MA, Hu Y and Inohara N: Caspases: the proteases of the apoptotic pathway. Oncogene 17: 3237-3245, 1998.

32. Kaufmann SH and Earnshaw WC: Induction of apoptosis by cancer chemotherapy. Exp Cell Res 256: 42-49, 2000.

33. Nimmanapalli R, Perkins CL, Orlando M, O'Bryan E, Nguyen D and Bhalla KN: Pretreatment with paclitaxel enhances apo-2 ligand/tumor necrosis factor-related apoptosis-inducing ligandinduced apoptosis of prostate cancer cells by inducing death receptors 4 and 5 protein levels. Cancer Res 61: 759-763, 2001.

34. Gliniak B and Le T: Tumor necrosis factor-related apoptosisinducing ligand's antitumor activity in vivo is enhanced by the chemotherapeutic agent CPT-11. Cancer Res 59: 6153-6158, 1999. 